The International Journal of Indian Psychology: Volume: 01 | Issue: 03 | ISSN 2348-5396

\title{
Self Compassion and Emotional Intelligence of Engineering and Dental College Students
}

\author{
Dr. Thiyam Kiran Singh*, Ms. Niharika Saini**
}

\begin{abstract}
$\underline{\text { Abstract }}$
Total samples of 60 were collected out of which 15 boys and 15 girls were engineering students and the remaining 15 boys and 15 girls were dental students. They were collected using simple random method from different departments of engineering of Amity University Rajasthan (AUR) and Jaipur dental college to compare self compassion \& emotional intelligence between Engineering and Dental college students using emotional intelligence scale and self compassion scale. The result found no difference in self compassion of Engineering and Dental students but there is difference in traits of emotional intelligence of boys of Engineering and Dental student. Again the result also found significant difference in overall comparison of Engineering and Dental students in the area of emotional intelligence which proclaim that Engineering students are better in emotional intelligence than Dental students.
\end{abstract}

Key Words: Self Compassion, Emotional intelligence, Engineering, Dental.

\section{Introduction}

Compassion is a feeling of deep sympathy and sorrow for another who is stricken by misfortune, accompanied by a strong desire to alleviate the suffering. There is an aspect of compassion which regards a quantitative dimension, such that individual's compassion is often given a property of "depth," "vigour," or "passion." More vigorous than empathy, the feeling commonly gives rise to an active desire to alleviate another's suffering. It is often, though not inevitably, the key component in what manifests in the social context as altruism (Kang, 2010).

\footnotetext{
*Assistant Professor and Clinical Psychologist, Dept. of Psychology, AIBAS, Amity University Rajasthan, Jaipur, Rajasthan

**M. Phil Student, Clinical Psychology Trainee at Dept. of Psychology, AIBAS, Amity University Rajasthan, Jaipur, Rajasthan
} 


\section{The International Journal of Indian Psychology: Volume: 01 | Issue: 03 | ISSN 2348-5396}

Self compassion is extending compassion to one's self in instances of perceived inadequacy, failure or general suffering .Neff has defined self compassion as being composed of three main components -self kindness, common humanity and mindfulness.

Emotional intelligence (EI) refers to the ability to perceive, control and evaluate emotions. Some researchers suggest that emotional intelligence can be learned and strengthened, while others claim it is an inborn characteristic. The ability to express and control our own emotions is important but so is our ability to understand, interpret and respond to the emotions of others. Psychologists refer to this ability as emotional intelligence and some experts even suggest that it can be more important than IQ (Cherry, 2014). Many researchers have been conducted on compassion and emotional intelligence on many different groups of population but the study on Engineering and Dental student populations are very rare. So this study will definitely enlightened about the psychological impact of compassion and EI on Engineering and Dental students. The implications of this study and its findings are potentially important to the process of teaching and learning. Understanding student's study approaches enables teachers to know basic ideas about their strategies of teaching and learning activities in order to help students improve their academic performance in relation to emotional intelligence.

\section{Methodology}

\section{Objective:}

To study the relationship between Self Compassion and Emotional Intelligence in college students of professional courses of dental and engineering.

\section{Hypothesis:}

1. There will be significant difference between Engineering and Dental students on Self Compassion

2. There will be significant difference between Engineering and Dental students on Emotional Intelligence

\section{SAMPLE:}

A total of 60 students were collected out of which 15 are male Engineer students, 15 are female Engineering students, 15 are male Dental students and remaining 15 are female Dental students. 
The International Journal of Indian Psychology: Volume: 01 | Issue: 03 | ISSN 2348-5396

\section{INCLUSION CRITERIA:}

1. Male and female students of Engineering and Dental.

2. Those who can give their consent for study.

\section{EXCLUSION CRITERIA:}

1. Students who are not studying engineering and Dental.

2. Those who can't give their consent for study.

\section{Tools Used}

\section{Emotional Intelligence:}

Emotional Intelligence Scale (EIS; Schutte et al., 1998). The EIS is a 33-item, 5-point (1 $=$ strongly disagree to $5=$ strongly agree) self-report measure of emotional intelligence based on Salovey and Mayer's (1990) theoretical model of emotional intelligence. This unifactor scale asks respondents to indicate their level of agreement with each item, and the possible range of scores for the EIS is 33 to 165 . The EIS was validated on a sample of participants who were recruited from a variety of settings, including university students and individuals from community settings. In the validation study, the EIS was found to be positively correlated with attention to feelings, clarity of feelings, mood repair, and optimism, and was reported to be negatively related to pessimism, alexithymia, depression and impulsivity (Schutte et al., 1998). Moreover, psychotherapists were found to have higher mean scores on the EIS than a group of female prisoners and a group of individuals in a substance abuse treatment program. Women in the validation study also scored significantly higher than male respondents. The EIS is reported to have good predictive and discriminate validity. Internal consistency reliabilities in the validation sample ranged from .87 to .90 , and a test-retest reliability coefficient of .78 was computed (Schutte et al., 1998). In this study, the Cronbach's alpha for the EIS was .87.

\section{Self Compassion:}

The Self Compassion Scale (SCS) was designed by Neff (2003) to measure self compassion in individuals. The SCS has been used in a number of studies within the past decade amid developments in the applications of meditation and mindfulness in western psychology. 


\section{The International Journal of Indian Psychology: Volume: 01 | Issue: 03 | ISSN 2348-5396}

The result has been a growing interest in the topic of self-compassion and its relationship to psychological functioning and phenomena. Since 2003, scores of studies have used the SCS as a measure of self-compassion with respect to a variety of psychological phenomena, measures, and tests. These findings will be discussed in detail in the sections to follow. The SCS is informed by Buddhist psychology and understanding of the self. This is evident in the phrasing of items on the scale and the structure of the measure. Furthermore, during its development factor analysis dictated that it be divided into six subscales including: self-kindness, self-judgment, common humanity, isolation, mindfulness and over-identification. Thus, the six subscales are the result of both theoretical and empirical findings. A total SCS score and subscale scores can be derived from the measure providing detail regarding the construct and its theoretical makeup. SelfCompassion Scale demonstrates good construct reliability and validity (Neff, 2003)

\section{PROCEDURE}

A total sample of 60 were collected randomly out of which 15 boys and 15 girls were Engineering students and the remaining 15 boys and 15 girls were Dental students. After taking permission from authorities of University and College samples were collected from different departments of Engineering of Amity University Rajasthan, Jaipur and Dental College, Jaipur. All the participants were given consent form to read before participation in the study. They were administered emotional intelligence scale and self compassion scale to assess their overall domains of emotional intelligence and self compassion.

\section{Statistical Analysis:}

Statistical analyses were done with the help of statistical methods of mean, standard deviation and t- test.

\section{Result:}

Table - 1 shows Comparison between boys groups and between girls groups of engineering and dental students. The result found no significant in both the groups of boys and girls of engineering and dental students. Table 2 shows the comparison between boys groups and between girls groups of engineering and dental students on Emotional Intelligence. The result find significant $\left(\mathrm{t}=2.16^{*}, \mathrm{P}<0.05\right)$ under the groups of boys which indicate that engineering 


\section{The International Journal of Indian Psychology: Volume: 01 | Issue: 03 | ISSN 2348-5396}

boys students are more sound in emotional intelligence than dental boys students. Table 3 shows comparison between overall engineering and dental students on Self compassion. The result found no significant difference. Table 4 shows comparison between overall engineering and dental students on Emotional intelligence. The result find significant $\left(\mathrm{t}=2.43^{*}, \mathrm{P}<0.05\right)$ which indicate engineering students are better in terms of emotional intelligence then dental students.

\section{DISCUSSION:}

The study found significant in comparison under the groups of boys on emotional intelligence which indicate that engineering boys students are comparatively more better in emotional intelligence than dental boys students. It may be because engineering students require more academic achievements. Accordingly, Ataabadi et al. (2014) found in their study that there is meaningful and positive relationship between emotional intelligence and academic achievement. On the other hand supportively, Winter and Dodou (2011) found in their study that high academic performance in physics, chemistry and mathematics would probably be a more useful predictor of overall academic performance in engineering. In another study of Skipper and Brandenburg (2013) Soft skills such as emotional intelligence are viewed as effective ways to distinguish potential high-performance workers. It is posited that high performing engineering students will also exhibit more proficiency at these 'soft skills' than engineering students with more modest academic success. The purpose of their study was to examine the relationship between Emotional Intelligence and academic performance and examine the potential difference in Emotional Intelligence with respect to demographic and experiential characteristics. The result found a positive connection between the amount of academic achievement and higher Emotional Intelligence scores.

The study also found significant in comparison between overall (Boys and Girls) engineering students and dental students on Emotional intelligence which indicate engineering students are better in emotional intelligence then dental students. This may be because high cognitive ability is required for engineer students in work for success. Similarly, Rindermann et al (2014) found in their study that engineers in order to become a successful engineers they require high cognitive abilities especially for work in research and development. Supportively, Sprunck (2013) found Emotional Intelligence is a key success factor for software engineers in business and private life. As Software Engineers emotions are usually not main focus in daily 


\section{The International Journal of Indian Psychology: Volume: 01 | Issue: 03 | ISSN 2348-5396}

work. Engineers require to work with others in teams as users and customers. Mostly they have no technical background and come from complete different domains. In another study of $\mathrm{Ng}$, Cheng, Check, \& Goh, (2013) the Engineering and IT students have higher Emotional Quotient as compared to Management student. The implications of these findings are potentially important to the process of teaching and learning. Understanding student's study approaches enables instructors to fine tune their strategies of teaching and learning activities in order to help students improve their academic performance.

\section{CONCLUSION}

From the above study it is concluded that there is no difference in self compassion of Engineering and Dental students. There is significant difference in emotional intelligence between boys groups of Engineering and Dental students. Again there is significant difference in overall comparison of Engineering and Dental students in the area of emotional intelligence which proclaim that Engineering students are better in emotional intelligence than Dental students. On the other side there is also no significant difference in self compassion and emotional intelligence between girls groups of Engineering and Dental streams.

\section{REFRENCES:}

1. Ataabadi, S., Yusefi, Z.,\& Moradi, A. (2014). Predicting academic achievement among deaf students: emotional intelligence, social skills, family communications and selfesteem. European Journal of Research on Education, 2(1) ,35-46. Retrieved from: http://iassr.org/rs/020105.pdf on 30/03/2014.

2. Cherry, K. (2014). What Is Emotional Intelligence?.Retrieved from: http://psychology.about.com/od/personalitydevelopment/a/emotionalintell.htm on $1 / 4 / 2014$.

3. Kang, R. (2010). Compassion. Retrieved from: http://rannykang.blogspot.in/2010/08/compassion.html on 1/4/2014.

4. Neff, K. D. (2003). The development and validation of a scale to measure selfcompassion. Self and Identity 2 (3), 223-250.

5. Ng, L.N., Cheng, L.T., Check, Y.L., \& Goh, W.W. (2013). Examining the Influence of Emotional Intelligence on Students' Study Approaches and Academic Performance. 


\section{The International Journal of Indian Psychology: Volume: 01 | Issue: 03 | ISSN 2348-5396}

International Proceedings of Economics Development \& Research, 44, 146. Retrieved from: http://connection.ebscohost.com/c/articles/83377001/examining-influenceemotional-intelligence-students-study-approaches-academic-performance on 30/3/2014.

6. Rindermann, H., Baumeister, A.E., \& Groper, A. (2014). Cognitive abilities of Emirati and German engineering university students. Journal of Bio Social Science, 46 (2), 199213.

7. Salovey, P., \& Mayer, J. D. (1990). Emotional intelligence. Journal of Imagination, Cognition, and Personality, 9, 185-211.

8. Schutte, N. S., Malouff, J. M., Hall, L. E., Haggerty, D. J., Cooper, J. T., Golden, C. J., \& Dornheim, L. (1998). Development and validation of a measure of emotional intelligence. Personality and Individual Differences, 25, 167-177.

9. Skipper, C.O., \& Brandenburg, S. (2013). Emotional intelligence and academic performance of engineering students. Engineering Project Organization Journal,3 (1),1321. Retrieved from:

http://www.tandfonline.com/doi/abs/10.1080/21573727.2012.738669?journalCode=tepo2 0\#.UzgAtCe6bXR on 30/3/2014.

10. Sprunck, M. (2013). Emotional Intelligence in Software Engineering. Retrieved from: http://www.sw-engineering-candies.com/blog-1/emotional-intelligence-in-softwareengineering on $30 / 3 / 2013$.

11. Winter, J.C.F. DE., \& Dodou, D. (2011). Predicting Academic Performance in Engineering Using High School Exam Scores. International Journal of Engineering Education, 27(6), 1343-1351. Retrieved from http://www.3me.tudelft.nl/fileadmin/Faculteit/3mE/Over_de_faculteit/Afdelingen/BioMe chanical_Engineering/Organisatie/Medewerkers/Winter/doc/19_ijee2519ns.pdf 0n $30 / 3 / 2014$. 
The International Journal of Indian Psychology: Volume: 01 | Issue: 03 | ISSN 2348-5396 Tables:

Table -1: Comparison between boys groups and between girls groups of engineering and dental students on self compassion Scale.

\begin{tabular}{|c|c|c|c|c|c|c|}
\hline Group & \multicolumn{3}{|c|}{ Boys } & \multicolumn{3}{|c|}{ Girls } \\
\hline & MEAN & SD & $\mathrm{T}$ & MEAN & SD & $\mathrm{T}$ \\
\hline Engineering & 2.97 & 0.31 & 0.09 & 3.14 & 0.42 & 0.77 \\
\hline Dental & 2.98 & 0.27 & & 3.04 & 0.33 & \\
\hline
\end{tabular}

* Significant at 0.05 level

** Significant at 0.01 level

Table 2: Comparison between boys groups and between girls groups of engineering and dental students on Emotional Intelligence.

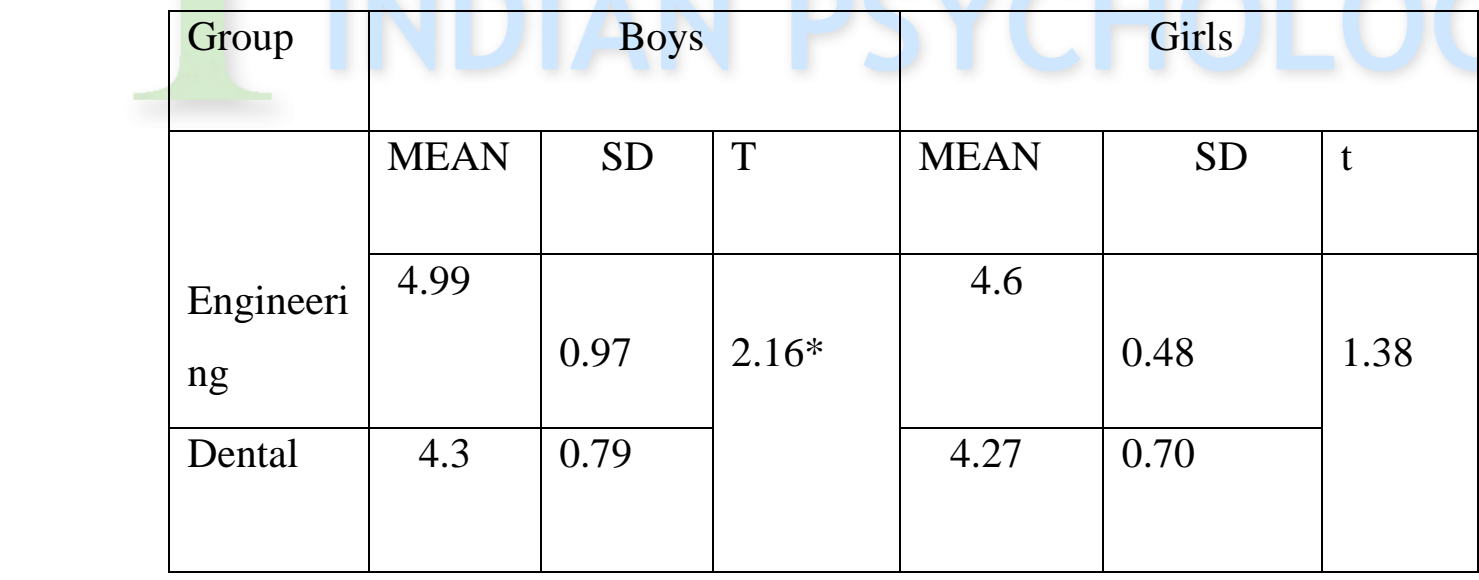

* Significant at 0.05 level

** Significant at 0.01 level 
The International Journal of Indian Psychology: Volume: 01 | Issue: 03 | ISSN 2348-5396 Table - 3: comparison between overall (Boys and Girls) engineering and dental students on Self compassion

\begin{tabular}{|l|l|l|l|}
\hline Group & MEAN & SD & $\mathrm{t}$ \\
\hline Engineering & 3.05 & 0.36 & \\
\hline Dental & & & \multirow{2}{*}{0.5} \\
& 3.01 & 0.3 & \\
\hline
\end{tabular}

* Significant at 0.05 level

** Significant at 0.01 level

Table-4: Comparison between overall (Boys and Girls) engineering and dental students on Emotional intelligence

\begin{tabular}{|l|l|l|l|}
\hline Group & MEAN & SD & $\mathrm{t}$ \\
\hline Engineering & 4.79 & 0.72 & \multirow{2}{*}{$2.43 *$} \\
\cline { 1 - 3 } Dental & & & \\
\hline
\end{tabular}

* Significant at 0.05 level

** Significant at 0.01 level 